\title{
Girls' Work in a Rural Intercultural Setting
}

\author{
Formative Experiences and Identity in \\ Peasant Childhood
}

Ana Padawer

$\cos$

\begin{abstract}
In this article I explore the meaning of work for girls in rural northeastern Argentina as formative experience that forges their identity as peasants in the contemporary world. Based on ethnographic research conducted from 2008 to the present in rural areas of San Ignacio (Misiones), I examine, from the perspective of regulatory definitions regarding children's work, the ways in which young girls gradually participate in the social reproduction of families. Girls' participation in these activities should not be romanticized as part of a socialization process, but, rather, critically considered as formative experience in which class, age, gender, and ethnic distinctions define certain tasks as girls' peasant skills. Using data from participant observations made on three farms, I show how girls have an active role in the appropriation of knowledge through shared activities with boys, although such learning is overshadowed by the prevailing socio-historic construct of male dominance.
\end{abstract}

Keywords: agrarian child workers, Argentina, gender, identifications, knowledge, social reproduction

This article is based on ethnographic research I started in 2008 as part of a team studying formative experience and identity among different ethnic groups in Argentina (Novaro 2011). I selected San Ignacio ${ }^{1}$ for my fieldwork because this rural area in the southern part of the Paraná jungle, located in the province of Misiones on the northeastern border of the country, has been for more than a century a place of interaction between members of an ethnically diverse population composed of Mbyà-Guaraní indigenous people, colonos (descendants of European immigrants) and a majority of criollos (offspring of conqueror Spaniards born in America, some of them with an indigenous parent).

My research focuses on the formative dimension of children's participation in agrarian work in the daily social construction of contrasting identi- 
ties. Specifically, I explore the meaning of work for girls as learning that builds their identities as peasants in the contemporary world. Regulatory definitions of children's work allow me to analyze how girls' participation in rural tasks should not be defined negatively as child labor, nor romantized as part of an idyllic parenting process. It should, instead, be conceptualized as an educational process, a formative experience in which class, age, gender, and ethnic distinctions define certain tasks as girls' peasant skills.

Using data from participant observations made on three farms, I will show how girls play an active role in the appropriation of knowledge through shared activities with boys, although such learning is overshadowed by the prevailing socio-historic construct of male dominance. By way of introduction, I will give a brief overview of four key concepts in my research-identity, children's work, formative experience, and male dominance-and will discuss how they all interrelate.

I should point out first that the concept of identity has been extensively debated in the field of anthropology over the past 40 years and has moved beyond the essentialist definitions that predominated during the first half of the twentieth century (Barth 1976). Constructionist positions on identity, including the classic work by Rogers Brubaker and Frederick Cooper (2000) proposed the concept of self-identification in order to incorporate the active role played by subjects in the production and attribution of meaning to differences, without losing their structural strength in social relationships. In this conceptual turn, anthropologist Claudia Briones (2007) argued some years ago that the work of indigenous identification operates according to circumstances that are not of their own choosing.

These contributions to the concept of ethnic identity allowed our team to study inter-cultural education in different zones of Argentina, with an emphasis on the processes of the appropriation of membership resources where successive generations had built changed frontiers. My interest has been in how activities tied to social reproduction fit into these ethnic identity-building processes, and in studying to what extent children`s participation in production activities on family farms could be defined as work and to what extent as learning (Padawer and Diez 2015).

Olga Nieuwenhuys's influential Children's Lifeworlds. Gender, Welfare and Labour in the Developing World (1994) set the stage for a series of anthropological studies on children's work in peasant settings in which their tasks within the context of family were clearly differentiated from work in waged employment; her distinctive contribution was to raise the issue of the former's economic relevance, but also to distinguish it from child labor. The 
book produced empirical evidence of children's exploitation by seniority and gender in peasant domestic groups associated with capitalism in India; it interrogated the morally neutral assumptions underlying children's agrarian work. Her argument was that such moral claims of neutrality arose from parental protection and aims related to socialization generally attributed to rural activities - both absent in industrial work, which has been used as an implicit pattern to define child labor.

Nieuwenhuys pointed out that morally neutral assumptions were based on convergent perspectives-the legal protection for children's work in industrial settings established in the nineteenth century, and both neoclassical and conventional Marxist economic theories in which agrarian domestic work was defined according to use-value instead of profit and capital growth. From this challenging point of departure for the discussion of children's work, my intention is to explore the idea that domestic tasks also have a formative meaning that must be examined critically. I agree with her that anthropologists studying the former colonies have romanticized the many forms of child-adult relations in terms of socialization patterns based on learning by doing, and conflicts of gender and age are rarely described.

To analyze girls' participation in rural work as formative experience, I have used Elsie Rockwell's (1986) critical definition of the relationship between culture and education that has allowed me to raise the issue of the relationship of my subjects to knowledge in the contexts of different institutional practices. If the formative content of school experience is not restricted to the curriculum but lies in the ways in which knowledge is transmitted - in the organization of teaching activities and the institutional relations that sustain the education process - then the formative experiences that occur outside of school (in families, communities, peer groups) may be considered in the same way.

In the case of the peasant girls I encountered during my fieldwork in San Ignacio, the formative experiences they acquired outside of school through their participation in rural activities were defined in terms of class, age, gender, and ethnicity, making certain activities and knowledge relevant for them. While this article will refer to all the structural dimensions of the girls' lives mentioned above, I will linger on the issue of gender in particular since it has been particularly salient in recent years of fieldwork, and I have not considered it in previous work that focused on class, age, and ethnic relations (Padawer 2013).

In recent years, a great deal has been written about gender relations. A substantial contribution to my work is the concept of male dominance 
defined by Pierre Bourdieu (2000), based on his fieldwork in Algeria. He showed how the use of technical objects, practices of rural spatial structuring, or body techniques produced an experience of the social world and its arbitrary divisions deemed natural, starting with the socially constructed division of the sexes. In my analysis of how male dominance is present in the everyday formative experiences of girls in San Ignacio, what I want to underline is not so much an inherent and permanent structural opposition, but its historic and daily construction: I want to describe the active and invisible role of girls learning by way of participation in daily activities with boys, as well as their restriction from taking part in these tasks as they grow older, in a context of class and age subordination and ethnic differences.

To introduce this argument, I will refer to my ethnographic research in San Ignacio that included participant observation in schools, farms, and indigenous villages, as well as open interviews, and statistical and geo-reference data. I will refer to three peasant families (the Costas, the Olguíns, and the Estrellas) I met as part of my fieldwork; girls' participation in domestic agrarian work emerged as particularly relevant to my critical analysis of the romanticizing approach to formative experiences and their role in forging identity for younger generations.

\section{An Intercultural Border Setting}

San Ignacio is a township located in a border region (Argentina, Paraguay, Brazil), with a city of 6,312 inhabitants, and 4,229 inhabitants living on family farms and in indigenous villages (Instituto Nacional de Estadísticas $y$ Censos 2010). The town was founded in 1610 as an indigenous mbyàGuaraní Jesuit Mission, later informally settled by criollos until the War of the Triple Alliance (1864-1870), when San Ignacio was founded as an agricultural colono's community (to an explanation of which contested term I will return presently) in 1907 . The initial European immigration waves to Misiones have been described as a State strategy to safeguard national borders and bring civilization to a wild, hostile jungle setting during the late nineteenth century (Bartolomé 2007; Wilde 2007).

The border location explains the ethnic diversity and the agrarian social structure. The Mbyà-Guaraní population became more marginalized as agricultural borders expanded (Gorosito 2005), while the non-indigenous occupation was made by great estates dedicated to forestry and livestock, and criollo and European colonos settled on 25-hectare farms devoted to an agri- 
culture-based economy, some of them accumulating wealth through the small-scale production of industrial crops such as ilex paraguarensis (yerba mate), tea, and manioc during the second half of the twentieth century (Abinzano 2013; Schiavoni 2008).

Despite the capitalization of some domestic units, and the European or criollo ancestry, country dwellers have used the term colonos as an identity marker-a contrastive identification against the Mbyá-Guarani peoplethrough generations, and still do so today (Brubaker and Cooper 2000). The elusive self-attributed category has been debated for the past 40 years among social researchers who refer to colonos as peasants (field workers without land or capital resources), farmers (land owners and agrarian producers with small properties) and categories in between as in Eduardo Archetti and Kristi Anne Stolen's classic study (1975). The colono identity included economic and ethnic connotations but it also involved a moral meaning. It embodied sacrifice, successful strategies of family reproduction in the country, and hard work (Mastrangelo and Trpin 2008), all of which are essential to the significance of girls' participation in agrarian tasks as formative experiences, as I will explain next.

\section{Girls' Work in the Countryside}

Sonia Costas was the first peasant girl I met when I began my fieldwork in 2008 in San Ignacio. An extract from my fieldnotes shows how I became familiar with her participation in domestic tasks, and how these tasks were barely acknowledged by her or her family in terms of knowledge or work; they conceptualized them merely as help.

On a July afternoon in 2009, twelve-year-old Sonia, her mother and I took a walk around the farm after lunch. As we toured the greenhouses of tomatoes, the cornfields and the pastures where the cattle grazed, they told me how they'd returned to the country when Sonia was just a baby, when her father inherited a farm, allowing him to leave his job as a carpenter in a border city. Sonia's father had grown up in the countryside, but her mother came from a small town, so moving to the country meant she had to learn all the rural skills. Sonia and her brothers had been included in those skills since they were little.

Mother and children have learned to level the soil and manage the temperature in a greenhouse, to use pesticides, to tie cows during milking to avoid getting kicked, to care for animals preventing conflicts between the males. Sonia would walk several kilometers daily to attend the rural school, and after returning home she performed all domestic and farm work with her mother. Despite all the rural tasks 
performed every day by mother and daughter, they were called helpers by Sonia's father and brothers, who work on the farm and in a carpentry shop they have in town. As we toured the farm, Sonia's mother talked about sacrifice and the reward of being a colono, of having given up the comforts of the city for a life that had provided her with moral benefits, because she was able to teach her children the value of work. (Visit to Costas family farm, July 2009).

Through my fieldwork with families like Sonias, I was able to analyze the gradual incorporation of the younger generation into the social reproduction of families, and their central role in the historical construction of contrasting identities forged through formative experiences related to agrarian tasks. Thus, the criollo and colono girls referred to themselves as chicas de la colonia (farm girls), while their female Mbyà-Guaraní schoolmates were called chicas de la aldea (Indian village girls). Girls like Sonia acquired certain ways of inhabiting rural space marked by distinctions in terms of ethnicity, gender, age, and social position by formative experiences involved in their everyday tasks on family farms: they were chicas de la colonia because they had learned how to tie cows, use pesticides, or level the soil; they did not learn about foraging in the forest or craft-making as the indigenous girls did.

It is important to note that girls' identity as peasants in the case of Sonia and her classmates were linked to what Miriam Forman-Brunell and Julie Eaton (2009) refer to as the subjective conception of them as a workforce; it was through their incorporation in domestic and rural work that girls and young women were taught about peasant issues in context where, following Paul Willis's (1977) notion, they creatively developed and ultimately reproduced the characteristics of farm life in practice. Following Nieuwenhuys's theoretical approach to children's work and Rockwell's definition of formative experiences, I found the influence of adult cultural practices to be the most effective preparation for incorporating young people into manual labor, but also discovered that learning peasants' tasks was what I would call true learning.

While children and youth have participated in family agricultural work in different sociocultural and historical contexts, this has become a central concern on government policy agendas in recent decades, coinciding with the deployment of national and international regulations aimed at eradicating child labor (Programa Internacional para la Erradicación del Trabajo Infantil [International program on the elimination of child labor] 2009). Although these regulations have constituted undeniable progress toward the safeguarding of young generations, I have found the regulatory positions on child and youth labor more accurate than the abolitionist ones because the former allow me to describe formative experiences gained through farm work and distinguish them from eradicable child labor, as I have mentioned earlier (Padawer 2013). 
Formative, work-related experiences among peasant boys and girls of San Ignacio were not difficult to identify. They included practically all the daily tasks associated with farms, except in critical situations in which some males-generally older than twelve, the age at which primary school ends for most children - were employed in low-skilled agricultural activities outside their farms that did constitute eradicable child labor. As we will see later, on the family farms the situations of play, education, and work overlapped in the daily lives of boys and girls who used adult tools for their games and, as Marcelo Larricq (1993) put it, were initiated into work through role-play and gradual incorporation into the domestic activities of social reproduction. There was a basic division of labor by sex on the farms I visited: girls like Sonia were initiated into caring for younger siblings, doing laundry, and cooking as main activities, but in vegetable gardening and yard work they were so-called helpers because their brothers were incorporated into the more physically and technically demanding aspects of farm work.

As I will show in the next fragments from my fieldnotes on a visit to the Olguín family farm, the children learned about plants and animals through play on the farm with their older siblings, gradually increasing their repertoire of knowledge about their natural surroundings through their involvement in activities on the land, where they went from what Jean Lave and Ettienne Wagner (2007) see as peripheral and subordinated participation to significant dominion over, and responsibility for, an activity over the course of a few years.

There was no explicit transmission of knowledge in this process, but, rather, an appropriation of cultural resources shaped from the immediate environment (Rockwell 1997), where the progressive comprehension of the outside world came from the learners' intention to undertake an activity. As Ruth Paradise and Barbara Rogoff (2009) have pointed out about children's learning in practice, peasant girls like Sonia are apprentices to people with expertise in their immediate environment - mainly their fathers and older brothers-in a creative process conducted by a person attempting to engage in an activity, rather than someone merely copying. The learning process is clearer in the next case I discuss.

\section{Formative Experiences}

During my first years in San Ignacio I visited the Olguín family. The eldest daughter (14) was in the beginning grade of the agricultural boarding 
school. Saúl (12), Micaela (10), and Alicia (8) were attending a rural primary school. One day in June 2011, I decided to accompany the three little ones on their daily $6 \mathrm{~km}$ return walk home. While we walked, the children told me that their father had quit his job as a lumber transporter that year and increased their cattle and pork livestock. When we got to the farm I saw 23 new calves and the grain mill that allowed the family to produce a balanced diet from their manioc, sugar cane, and maize crops. Even though I had seen the children feeding the animals on previous visits, the volume of livestock their father had taken on that year had led him to hire a farmhand to harvest the crops destined for animal feed. So now that they were back at school, one of the children's tasks was to carry the harvested sugar cane and manioc from the truck to the mill, and from there to the corral to feed the animals.

On my visits to the Olguín farm, I noted that the children's role in rural activities was directly linked to adult availability and priorities. As long as the father's main source of income was from transporting lumber, the children took care of harvesting the crops and feeding the few animals they raised for their own consumption. When the livestock production was reconfigured, the adults who had worked with the father in the lumber business shifted their work to harvesting animal feed crops while the children began to help with the hauling. Thus, even though the children had to walk long distances to school and then had tasks to do when they got home, their parents went about re-assigning their different responsibilities in an effort to diminish the intensity of their labor (in this case, changing from harvesting to hauling crops).

Aside from this task, the children tended the family vegetable garden daily. Since I visited them on this occasion in winter, I was able to observe how the youngest children removed some plastic protectors placed on the rows of plantlets to water them. While we walked around the garden, they told me what plants we could see in each spot, how long ago they had been planted, and what kind of care they required.

Micaela: I'm not really sure what's planted here. Saúl?

Alicia: I know; it's parsley. There's one here, here, here ... (she points out the shoots in the soil). And what's this one (looking at her brother)?

Saúl: That's oregano.

Ana: Do you have to water every day?

Saúl: Yes, you have to water because it's dry. (Moving his foot over the surface,)

See how the soil is dry?

Alicia: These are radishes. 
Micaela: Careful with the mint! (She warns her little sister, who turns to step around some small shoots.)

Saúl: There's broccoli here, pointed cabbage...

Micaela: These are strawberries my sister brought from [agricultural high] school.

Ana: This jar you put around the strawberries, what's it for? (There are little plastic jars covering each plant. )

Micaela: In case it freezes, we cover them with the jar and then with plastic. Before watering them we take the jars off and leave the tarp for shade so the sun won't burn them. We water them in the afternoon. Cover it, Alicia!

Alicia: Come help me ...

Each girl goes to one end of the nursery, they extend the plastic cover and place boards to hold it down. (Visit to Olguín farm, June 2011)

When the Olguín children participated in the harvest and fed the animals, they learned different things: how to select and give the proper amount of feed; how to recognize when the animals were hungry; and how to bring them to the corral for feeding. But these learning processes through incorporation into work were even more evident in the family vegetable garden, an activity in which the children always had a role, regardless of the family's main productive activity. As can be seen in my earlier work (Padawer 2016) as well as in the fragment above, children's incorporation in activities on the land begins with simply walking around the farm learning how to be careful not to step on seedlings, gathering seeds or flowers, and interacting with the animals by feeding, calling, and playing with them. They learn this way through guided rediscovery (Ingold 2002), in which verbal explanations come from the activities in domestic contexts. The Olguín children were not given abstract information about plants but they learned to look at and identify crops in a natural setting where they were guided in the learning process by their older and more expert brothers and sisters.

While the Olguín children participated in daily family farm activities, their position in a sibling order defined by age and gender played a role in the tasks assigned to each. Since the oldest daughter is away from home for periods of time (two weeks a month), the ones with the most responsibilities in the domestic group were Saúl and Micaela. But even when the older sister was at home, Saúl was the one in charge of most skilled tasks like handling the machete, and heavy work such as hauling crops. The auxiliary position ascribed to girls was similar to the one I presented at the beginning of this article in relation to Sonia and her mother: it was their gender that placed them in a subordinate position in terms of adult ideals projected onto everyday tasks on farms. 
Although girls have access to formal education in agro-technology (like Saúl's sister), the main organizational tasks related to the crops were a male domain. Saúl was the one in charge of explaining the organization and care of herbs through everyday language and sensory experiences ("See how the soil is dry?"). It was the boy who was given the responsibility of planting and who could more easily identify the seedlings. This is why his sisters asked him about it ('I'm not really sure what's planted here. Saúl?).

During our walk around the garden, Micaela also participated actively in the explanations based on what she knew. But by asking her brother, and especially in watching after her younger siblings and warning them not to step on sprouts, Micaela was guiding her sisters to learn, to notice, and to identify herbs in their environment. Her younger sister, Alicia, also identified some herbs on her own, which she mentioned at different times. The identification of plants growing in the garden allowed the children to display their abilities to perceive shapes, colors, and textures through processes that they had acquired by appropriation of knowledge from their siblings, even though none of this came in the purposeful form of explicit schooling. It is important to note how, in the case of the eight- and ten-year-old girls, Micaela and Alicia, gender differences were not as marked as they were in the case of the twelve-year-old Sonia who was explicitly introduced as her brother's helper. I explore social differences more in the next case, which is about the Estrella family.

\section{Peasant Life: Gender, Class, Age, and Ethnic Identity}

The domestic responsibilities held by girls on the farm were linked to historical divisions along gender lines; this has been an issue in anthropological studies of kinship. Researchers have stated that, despite the diverse forms acquired by domestic groups around the globe, and despite history, dominant positions held by family members depend on the resources accessible to each one (Schiavoni 2003). In rural contexts like San Ignacio, this means inter-generational reproduction of differentiated control over land resources, technology, and income between males and females, reinforced through uneven distribution of skills and knowledge linked to a gender-based division of labor. In notions attached to the gender-based division of labor, girls are associated with domestic work where childcare and housework are perceived as developing their so-called natural abilities. In contrast, their brothers develop skills in rural agricultural work and they inherit farms. In this 
sense, as gender studies on rural productive units have shown, unequal access to opportunities for skill-learning reproduces the division of labor by sexa powerful tool of social restriction against women (Stolen 2004).

Within the construction of gender in this context, male dominion is not a given, but is produced daily. This can be seen in the visit I made to the Estrella family, where I explored the farm, accompanied by nine-yearold Luciano and eight-year-old Patricia, who carried a baby in her arms. Her brother sometimes gave her a hand, but it was made apparent by the small machete he carried in his belt that certain tools and tasks belonged to each separately.

Patricia: ... I'm going to look for manioc.

Luciano: Here's one. There are more over there. Around there there's watermelon, melon, onion, garlic.

Patricia: ... My mom and dad planted the watermelon and the melon. Where are the melons, Luciano? (I had been carrying the baby for a while and passed him to Patricia.)

Ana: He’s heavy!

Patricia: At home, we always take turns with the baby. When one gets tired, you pass him on to the other.

Luciano: This is a melon.

Ana: You remember where it was? (The plant is small; we walked a lot to find it.)

Luciano: I remember and see it. (Patricia passes me the baby again.)

Patricia: The baby likes to walk around the forest and be talked to.... We tell him: 'Look!' And he recognizes the birdies.

Luciano: This is weed.

Patricia: It's just for decoration [laughs].

Luciano: No, to keep the bugs away. My dad cleared out here, see? ... He uses this to measure. He puts one stick here, takes another over there, so he can plant below the [string] line to keep the plants straight.

Patricia: He squats down and checks to see if the line is straight. If it moves, he twists it tight, so the plants will be really straight!

The youngest siblings, Gerardo (7) and Andrea (5) get around the farm on their own. They show up and chase each other through the plants, tripping and laughing.

Patricia: We walk every day. We used to play in the woods with our cousins. Not anymore, because they're cutting down the trees. (She points to some men with heavy machinery working in the forest near us.)

Ana: Don't you get bored when you can't go to the woods?

Patricia: When I get bored, my mom sends me to do the laundry.

(We watch Gerardo and Andrea playing in the corn for a while.) 
Patricia: They're picking it to take it to the sow. (They fall down, laugh, the boy climbs a tree.) Andrea, careful of your clothes! (Visit to the Estrella family farm, November 2013.)

In this conversation I had with the children during our walk around the farm, it was again the oldest brother who knew what was planted in different places and could quickly identify isolated plants ("I'm going to look for manioc.") Even though Patricia was only one year younger than Luciano, her gender and position among the siblings left her with less access to these formative experiences. In fact, her brother corrected her several times on the identification or use of certain plants (“... no, to keep the bugs away.”) However, Patricia knew how to handle the machete her brother carried and had also learned how her father used a homemade tool ("he uses this to measure") to align the furrows.

Far from the stereotypical images of children engaged in child labor, the Estrella children climbed trees, picked fruit and vegetables that they learned to distinguish when wandering the farm and forest daily ("we walk every day"), playing and incorporating the tasks that were adult responsibilities ("they're picking corn for the sow" [and] "my dad cleared out here"). Even though they carried out activities that were socially approved of in terms of age and gender ("when I get bored, my mom sends me to do the laundry"), the influence of activities considered to be male knowledge ("he squats down and checks to see if the line is straight") were shared in early childhood by girls.

The domestic duties of girls like Patricia, conducted from an early age, were subordinated formative experiences. This subordination was not related to their duties of domestic work, but from the progressive restriction of access to the resources and skills related to farm work for girls, which was particularly salient given the influences of peasant tasks (later of male dominion) in the first decade of their lives.

The power relations produced within domestic groups in San Ignacio subordinated girls' positions in their progressively differentiated access to resources as they reached adolescence. In these configurations, peasant girls learned domestic work necessary for the reproduction of the family group, and, although the male tasks on the farm influenced their daily lives at an early age, they were overshadowed by the predominant mandate of women's roles as caregivers and homemakers. Girls' knowledge about agrarian tasks become less visible and accessible as they grow.

It is important to note that, while for some families there is a possible horizon of social mobility attainable through agricultural secondary school, where girls can also enroll (as in the case of the eldest Olguín daughter), 
adults project continuity and technical improvements to farm life onto their sons. In this way, girls continue studying at school to "learn more about farm life," but this knowledge is conceptualized as help for their future husbands, and for them "not to be afraid to get their nails dirty," as the mother of the Olguín children pointed out.

\section{Conclusions}

Participation by peasant girls in rural tasks must be considered in light of the distinction between children's work and child labor. Differentiating between the two concepts allows us to determine, according to each concrete historical and social situation, the characteristics of the ways in which the younger generations are incorporated in work so as to protect them when necessary, but also to examine critically romanticized ideas of learning-bydoing, and to consider children's participation in social reproduction activities as learning, without positive or negative moral idealizations.

The peasant girls I met in San Ignacio showed me that farm work allowed them to learn by practice in situations conditioned by class, age, gender, and ethnicity where tasks performed daily (in doing what was thought of as helping their fathers and brothers in defined spaces like the house and garden), body techniques (the care of siblings while walking), and objects (housekeeping tools) were legitimate feminine domains. The formative experiences effectively produced, however, went beyond expected roles: little girls were perfectly capable of distinguishing seedlings cultivated in the forest, and they could participate on equal terms with their brothers on the farm, but their opportunities diminished, and their capacities were overshadowed at adolescence. By this age, certain areas were gradually cut off from them as male domains, especially the handling of tools and machinery. Even if all girls knew how to handle machetes, their brothers were the ones who carried them in their belts every day and only boys were taught how to drive motor vehicles. The description of girls' work (even by their mothers and fathers) as help showed that they were put in a subordinate place compared to boys. In this sense, the legitimate peripheral participation by girls was part of a pattern of the gender-based division of labor passed down from generation to generation. Even though the girls knew how to do these tasks, this knowledge was actively disregarded.

Peasant girls were not usually hired for piecemeal work (like their brothers over the age of twelve). As they wandered around the farms, the girls 
were involved in a fluid series of activities alongside their brothers that went from games to learning to work, even when their gender required them to become responsible for domestic (household) tasks that restricted their possibilities of acquiring certain skills on the farm. Recognizing the formative nature of this flow of activities is important because it removes rural tasks from the exclusive domain of adults. Sharing everyday productive activities is a process that rarely occurs in urban middle-class contexts, and this productive segregation is made at the expense of an alienation of children's capacities for autonomy (the implied parameter for normalcy in child labor regulations). This does not imply a disregard for the importance of protecting children; on the contrary, it aims to safeguard their rights to a school education but also an education that allows them autonomy in their own social reproduction.

\section{Acknowledgments}

I thank the editors and reviewers for their comments and suggestions on this article. I recognize the families of San Ignacio for their warmth and patience during my fieldwork over many years. The National Council of Scientific and Technological Research (CONICET), the National Agency of Science and Technology Promotion (ANPCyT), and the University of Buenos Aires (UBA) have supported my research since 2008.

$\cos$

Ana PADAWER is Professor of Methodology at the Department of Anthropology at the University of Buenos Aires (Argentina). As a researcher of the National Council of Scientific and Technical Research (CONICET), she has been conducting fieldwork about knowledge and practice in rural and indigenous settings since 2008. She has published chapters in Ethnography and Education Policy across the Americas (2002), Ethnographies of Science Education (2014) and Phenomenology of Youth Cultures and Globalization (2015), and articles in scientific journals such as Ethnography and Education, Global Studies of Chilhood, Horizontes Antropologicos, Cuicuilco, Anthropologica, and Amazonica. E-mail: apadawer66@gmail.com 


\section{Note}

1. The names of the people in this paper are fictitious to preserve their anonymity, but the town mentioned is real because land conflicts are frequent in the area, and anthropological studies can help the peasants in cases of litigation.

\section{References}

Abinzano, Roberto. 2013. "Estudios antropológicos en y de la región de fronteras: cuestiones de teoría y metodología." Revista Ideacao 15 (2): 149-175.

Archetti, Eduardo, and Kristi Anne Stolen. 1975. Explotación familiar y acumulación de capital en el campo argentino. Buenos Aires: Siglo XXI Editora.

Barth, Fredrik. 1976. Los grupos étnicos y sus fronteras. México: Fondo de Cultura Económica.

Bartolomé, Leopoldo. 2007. Los colonos de Apóstoles: estrategias adaptativas y etnicidad en una colonia eslava en Misiones. Posadas: Editorial Universidad Nacional de Misiones.

Bourdieu, Pierre. 2000. La dominación masculina. Barcelona: Anagrama.

Briones, Claudia. 2007. "Teorías performativas de la identidad y performatividad de las teorías." Tabula Rasa 6: 55-83.

Brubaker, Rogers, and Frederick Cooper. 2000. "Beyond Identity." Theory and Society 29: 1-47.

Forman-Brunell, Miriam, and Julie Eaton. 2009. “The Graceful and Gritty Princess. Managing Notions of Girlhood from the New Nation to the New Millennium." American Journal of Play 1 (3): 338-364.

Gorosito, Ana Maria. 2005. "Liderazgos guaraníes, breve revisión histórica y nuevas notas sobre la cuestión.” Paper presented at VI Reunión de Antropología del Mercosur. Universidad Nacional de la República. Montevideo, 16 November.

Ingold, Tim. 2002. The Perception of Environment. London: Routledge. Instituto Nacional de Estadísticas y Censos. [Argentine National Institute of Statistics and Census.] 2010. "Censo Nacional Población y Vivienda de la Argentina.” http://www.indec.gov.ar (accessed 20 October 2012).

Larricq, Marcelo. 1993. Ipytüma. Construcción de la persona entre los Mbyaguarani. Posadas: Editorial Universidad Nacional de Misiones.

Lave, Jean, and Etienne Wenger. 2007. Situated Learning: Legitimate Peripheral Participation. Cambridge: Cambridge University Press.

Mastrangelo, Andrea, and Verónica Trpin. 2008. "Etnografía e historia de las relaciones interétnicas. Nativos y antropólogas en el Alto Paraná misionero." 
In Desarrollo y Estudios Rurales en Misiones, ed. Leopoldo Bartolome and Gabriela Schiavoni, 293-319. Buenos Aires: Ciccus Editora.

Nieuwenhuys, Olga. 1994. Children's Lifeworlds. Gender, Welfare and Labour in the Developing World. London: Routledge.

Novaro, Gabriela. 2011. La interculturalidad en debate. Buenos Aires: Biblos.

Padawer, Ana. 2013. "Mis chicos caen cualquier día en la chacra y no van a pasar hambre porque ellos saben: oportunidades formativas y trabajo en el sudoeste de Misiones-Argentina." Revista Trabajo y Sociedad 22: 87-101.

Padawer, Ana. 2017. "Temporal Dimensions of Childhood, Youth, and Adolescent Experiences: A Conceptual Discussion." Global Studies of Childhood 7 (3): 241-254. doi: 10.1177/2043610616671067

Padawer, Ana, and Maria Laura Diez. 2015. "Desplazamientos y procesos de identificación en las experiencias interculturales de vida de niños indígenas y migrantes en Argentina.” Anthropologica XXXIII (35): 65-92.

Paradise, Ruth, and Barbara Rogoff. 2009. "Side by Side: Learning by Observing and Pitching in." Ethos 37 (1): 102-138. doi 0.1111/j.1548-1352.2009. 01033.x

Programa Internacional para la Erradicación del Trabajo Infantil. 2009. Trabajo infantil Indigena. Una aproximación conceptual. Lima: International Labour Organization. http://www.ilo.org/ipec/programme/lang—en/index.htm (accessed 20 November 2012)

Rockwell, Elsie. 1986. "De huellas, bardas y veredas: una historia cotidiana en la escuela." In La escuela, lugar del trabajo docente, descripciones y debates, ed. Elsie Rockwell and Ruth Mercado, 15-30. México: Departamento de Investigaciones Educativas. Instituto Politécnico Nacional.

Rockwell, Elsie. 1997. "La dinámica cultural en la escuela." In Hacia un currículum cultural. La vigencia de Vygotski en la educación, ed. Alicia Alvarez, 21-38. Madrid: Infancia y Aprendizaje.

Schiavoni, Gabriela. 2008. "Nuevas organizaciones agrarias. Plantadores y campesinos en el nordeste de Misiones." In Campesinos y agricultores familiares. La cuestión agraria en Misiones a fines del siglo XX, ed. Gabriela Schiavoni, 99-132. Buenos Aires: Ciccus Editora.

Schiavoni, Lidia. 2003. "Aportes de hijas e hijos a las estrategias de vida familiar. Familias pobres urbanas y rurales de la provincia de Misiones." In Familia, trabajo y género. Un mundo de nuevas relaciones, ed. Catalina Wainerman, 153-198. Buenos Aires: Fondo de Cultura Económica.

Stolen, Kristi Anne. 2004. La decencia de la desigualdad. Género y poder en el campo argentino. Buenos Aires: Antropofagia.

Wilde, Guillermo. 2007. "De la depredación a la conservación. Génesis y evolución del discurso hegemónico sobre la selva misionera y sus habitants." Ambiente y Sociedade X (1): 87-106.

Willis, Paul. 1977. Learning to Labour. Farnborough: Saxon House. 